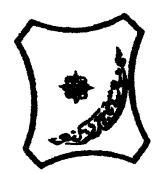

Bayero Journal of Pure and Applied Sciences, 9(1): 62 - 67

Received: January, 2016

Accepted: April, 2016

ISSN $2006-6996$

\title{
YIELD RESPONSE OF COWPEA VARIETIES TO SOWING DATES IN A SUDAN SAVANNAH AGROECOLOGY OF NIGERIA
}

\author{
Ewansiha, S.U. ${ }^{1,2 *}$ and Tofa, A.I. ${ }^{2}$ \\ ${ }^{1}$ Presently in the Department of Crop Science, Faculty of Agriculture, University of Benin, PMB 1154, Benin City, \\ Nigeria; ${ }^{2}$ International Institute of Tropical Agriculture, Kano Station, PMB 3112, Kano, Nigeria. \\ *Corresponding author: sylvester.ewansiha@uniben.edu, +2348056351478 or +2348134920763
}

\begin{abstract}
In the Sudan savannah of Nigeria, sowing date of cowpea is an important production constraint due to erratic rainfall at the beginning and towards the end of the rainy season when temperatures are high. Field trials were conducted during the rainy seasons of 2009 and 2010 at Minjibir (lat $12^{\circ}$ $08 ' \mathrm{~N}$, long $08^{\circ} 32^{\prime} \mathrm{E}$, elevation $508 \mathrm{~m}$ above sea level) in Sudan savannah of Nigeria, to determine the appropriate date of sowing of some recently developed cowpea varieties. Split-plot design was used with three replications. Sowing dates (10 July, $17 \mathrm{July,} 24 \mathrm{July}$ and $31 \mathrm{July}$ ) were assigned to main-plots and cowpea varieties (IT98K-205, IT97K-499-35, IT98K-573-2-1, IT89KD-288 and IT99K-241-2) were assigned to sub-plots. The results showed significant differences among cowpea varieties for yield and yield components. Sowing date significantly affected the performance of the five-cowpea varieties. Interaction between sowing date and variety was not significant for grain yield, suggesting that the varieties responded similarly to sowing date. Cowpea sown on 31 July produced significantly higher number of pods, number of seeds and grain yield compared with other sowing dates. Increase in grain yield for a sowing date relative to 10 July sowing was 26, 77 and 106\% for 17, 24 and 31 July sowing, respectively. The medium maturing variety IT98K-573-2-1 significant/y produced the highest number of pods, number of seeds and grain yield at all sowing dates. Based on these findings, for obtaining optimum yield, cowpea varieties should be sown at the end of July while for maximum yield, medium maturing cowpea varieties such as IT98K-573-2-1 are recommended.
\end{abstract}

Key words: Vigna unguiculata; grain yield; fodder yield; Sudan savannah

\section{INTRODUCTION}

Cowpea (Vigna unguiculata (L.) Walp) is a food and feed crop grown in the semi-arid tropics of Africa, where Nigeria is the largest producer and consumer, accounting for $61 \%$ of production (IITA, 2009). Cowpea's high protein content, its adaptability to different types of soil and intercropping systems, its resistance to drought, and its ability to improve soil fertility and prevent erosion makes it an important economic crop in many developing regions. The sale of the stems and leaves as animal feed during the dry season also provides a vital income for farmers. In Africa humans consume the young leaves, immature pods, immature seeds, and the mature dried seeds (IITA, 2009).

Sowing date for cowpea varies from area to area depending on the establishment of rains, light and temperature. According to Gallagher and Biscoe (1978), sowing at optimum time enables the crop to best use the available growth factors such as temperature and solar radiation at different stages of growth for high productivity. Weber et al. (1995) reported that more than $90 \%$ of farmers in Northern Nigeria take the risk of planting early as a strategy to capture a bonus from early crop sales, avoid pest and diseases attack and increase crop yield by intercepting the nutrient flush that comes with the first rain.
However, crops are often subjected to drought stress in both seedling and terminal growth stages, which causes substantial reduction in growth and grain yield. Despite the importance, adaptability, wide area coverage and yield potential of cowpea, the crop is insufficiently produced by local farmers and yields are low and inconsistent because in the savannah ecological zones, sowing date of cowpea is an important production constraint due to erratic rainfall at the beginning and towards the end of the rainy season when temperatures are high. Early sowing has reportedly enabled cowpea to escape high temperatures during the flowering stages when the crop is sensitive to heat (Hall, 2012). However, farmers grow photosensitive cowpea varieties which require late sowing (Kamara et al. 2010a).

Yield potential of cowpea is high, averaging 1.5 to 3.0 t/ha under cowpea sole crops with optimum management (Muleba and Ezumah, 1985). Each variety has a maximum yield potential that is genetically determined. This genetic yield potential is realised only when management and environmental conditions are complementary (Ehlers and Hall, 1996). Although weather condition cannot be predicted during the growing season, use of the right variety can help to minimize weather related risk (Patel and Hall, 1996). 
Several cowpea varieties are available that were recently bred by the International Institute of Tropical Agriculture (IITA, 2009). These varieties are diverse in maturity and growth habit and may require differing management approach that includes, among others, choice of proper sowing date. Sowing appropriate cowpea varieties at proper sowing date that does not conflict with the periods when staple foods make high labour demands and that allows pods to mature during dry, bright, sunny weather would support high cowpea production and tolerance to low precipitation and high temperatures that characterize the Sudan savannah ecological zone. Nonetheless, significant interaction between sowing date and cowpea variety may mean improved yield as cowpea specific for particular sowing date would be identified. In a recent publication, Kamara et al. (2010a) suggested that early and medium maturing cowpea varieties should be sown in mid-August and sprayed twice, whereas late-maturing indeterminate varieties should be sowed in early August and sprayed thrice in the savannahs of North-eastern Nigeria. Location may influence cowpea response to planting date of cowpea. Thus, this paper reports the yield response of new and diverse cowpea varieties to differing sowing dates in a Sudan savannah agroecology of North-western Nigeria.

\section{MATERIALS AND METHODS}

The experiment was conducted during the rainy seasons (July-November) of 2009 and 2010 at the research farm of the International Institute of Tropical Agriculture (IITA), Minjibir (lat $12^{\circ} 08^{\prime} \mathrm{N}$, long $08^{\circ} 32^{\prime} \mathrm{E}$, elevation $500 \mathrm{~m}$ above sea level), $40 \mathrm{~km}$ north-east of Kano. Minjibir is in the Sudan savannah and has an average annual rainfall of $690 \mathrm{~mm}$ and a growing period of about 120 days; soils are classified as typic Utipsamments and are loamy sands (Ewansiha et al., 2015). The soil at the time of experimentation had a sand content of $830 \mathrm{~g} \mathrm{~kg}^{-1}$, silt $80 \mathrm{~g} \mathrm{~kg}^{-1}$, clay $100 \mathrm{~g} \mathrm{~kg}^{-1}$, organic carbon $4.1 \mathrm{~g} \mathrm{~kg}^{-1}$, total nitrogen $0.31 \mathrm{~g} \mathrm{~kg}^{-1}$, Mehlich $\mathrm{P} 15.57 \mathrm{ug} / \mathrm{g}, \mathrm{K}^{+}$ $0.13 \mathrm{cmol} \mathrm{kg}^{-1}$ and a pH of 5.8. Mean minimum (22.8 in 2009 and 21.3 in 2010) and maximum (32.7 in 2009 and 34.9 in 2010) temperatures were not different for both years. Total rainfall of $757 \mathrm{~mm}$ and $999 \mathrm{~mm}$ was recorded for 2009 and 2010, respectively. The experimental plot had a previous history of cowpea cultivation.

Five cowpea varieties (IT98K-205, early maturing, IT97K-499-35 and IT98K-573-2-1, medium maturing and IT89KD-288 and IT99K-241-2, late maturing) developed by IITA (IITA, 2009) were sown. The treatments consisted of sowing date (10 July, 17 July, 24 July and 31 July) and the cowpea varieties. The experiment was laid out in a split-plot design. Sowing dates were assigned to the main plots while cowpea varieties were assigned to the subplots. The experiment had three replications while a subplot measured $3.0 \mathrm{~m} \times 5.0 \mathrm{~m}$, and contained four ridges spaced $75 \mathrm{~cm}$ apart.

Land was disc-harrowed and ridged. Cowpea seeds were sown on 10,17, 24 and 31 July in 2009 and 2010 at a spacing of $75 \times 20 \mathrm{~cm}$. Three seeds of the crop were planted per hole. These were thinned to two plants per stand one weeks after sowing, giving a cowpea plant population of 133,333 plants ha ${ }^{-1}$. Mineral nutrients, $\mathrm{N}, \mathrm{P}$ and $\mathrm{K}$ in the form of NPK 15:15:15 at a rate of $15 \mathrm{~kg} / \mathrm{ha}$ each and Phosphorus as $\mathrm{P}_{2} \mathrm{O}_{5}$ in the form of SSP at a rate of $50 \mathrm{~kg} / \mathrm{ha}$ were applied at the time cowpea seeds were sown. During the vegetative, flowering and podding stages, cowpea plants were sprayed with Karate $(50 \mathrm{~g} / \mathrm{l}$ lamdacyhalothrin, manufactured by Syngenta Crop Protection AG, Basle, Switzerland) at a rate of $1.0 \mathrm{l} / \mathrm{ha}$ when the first few insects were noticed. At sowing, a mixture of pendilin $(500 \mathrm{~g} / \mathrm{l}$ pendimethalin, manufactured by Meghmani Industries Limited, India) and Gramoxone (1:1-dimethyl-4, 4-bipyridinum dichloride, manufactured by Syngenta Crop Protection AG, Basle, Switzerland) at a rate of $1 \mathrm{~L} /$ ha each, were applied as a pre-emergent herbicide. Thereafter, plots were weeded using hoes just before flowering.

At pod maturity, all the plants in a quadrat measuring $1.5 \mathrm{~m}^{-2}$ placed across the two middle rows that made the net plot were harvested to calculate number of pods $\mathrm{m}^{-2}$ and number of seeds $\mathrm{m}^{-2}$. Pods on plants from the remaining net plot were harvested, sun-dried and hand-threshed. Grain yield for each remaining net plot was weighed and added to those from the quadrat area to make net plot grain yield. The moisture content of grain samples from each plot was determined using Farmex MT-16 grain moisture tester and final grain yield ha ${ }^{-1}$ adjusted to $14 \%$ moisture content was calculated. Mean 100-seed weight was recorded for each plot. For fodder yield determination, leaves and stems from the harvested plants in each net plot including those from the quadrat area were rolled up together and left on the plot to sun-dry to a constant weight. This was calculated as fodder yield in $\mathrm{kg} \mathrm{ha}^{-1}$.

Combined analysis of variance (ANOVA) for the twoyear data was performed using the Generalized Linear Model (GLM) procedure of SAS (SAS Institute Inc, 2011). Replication was treated as random effect and sowing date and cowpea variety as fixed effects in determining expected mean square and appropriate $F$-tests in the ANOVA. Differences between two treatment means were compared using LSD at $5 \%$ level of probability as calculated by LSmeans option pdiff of SAS.

\section{RESULTS}

Year had a significant effect on number of pods $\mathrm{m}^{-2}$, number of seeds $\mathrm{m}^{-2}$, seed weight, fodder yield and grain yield (Table 1 ). There was $23.9 \%$ increase in the number of pods $\mathrm{m}^{-2}$ in 2010 compared with 2009. However, number of seeds $\mathrm{m}^{-2}$ was $26.9 \%$ higher in 2010 than in 2009. For seed weight, seeds were heavier by $10.7 \%$ in 2009 than in 2010 . Fodder yield and grain yield were $49.9 \%$ and $18.7 \%$ higher in 2010 compared with 2009, respectively.

A summary of the results of sowing date effect on number of pods, number of seeds, seed weight, fodder yield and grain yield is presented in Table 1 . Sowing date influenced number of pods $\mathrm{m}^{-2}$. A significant increase in mean number of pods occurred as sowing date was delayed from 10 July to 31 July. Number of seeds $\mathrm{m}^{-2}$ varied significantly among the sowing dates. 
Bajopas Volume 9 Number 1 June, 2016

Number of seeds generally increased with delayed sowing. The highest number of seeds was recorded when cowpea was planted on 31 July and was not different from that obtained for 24 July sowing, an increase of $72 \%$ and $36 \%$ over 10 and 17 July sowing, respectively. Seed weight and fodder yield were not affected by sowing date. Sowing date, however, significantly affected grain yield. Mean grain yield increased progressively from 10 July sowing to 31 July sowing for all varieties. Increase in grain yield for a sowing date relative to 10 July sowing was 26 , 77 and $106 \%$ for 17,24 and 31 July sowing, respectively.

Number of pods, number of seeds, seed weight, fodder yield and grain yield as influenced by variety are presented in Table 1. Varietal differences occurred for number of pods $\mathrm{m}^{-2}$. Variety IT98K-573-2-1 produced the highest number of pods $\mathrm{m}^{-2}$; IT89KD288 had the lowest number of pods $\mathrm{m}^{-2}$, while IT98K205, IT97K-499-35 and IT99K-241-2 bore similar number of pods $\mathrm{m}^{-2}$. The difference in number of seeds due to variety was highly significant. The highest number of seeds was obtained in IT98K-5732-1 and the lowest was produced by IT89KD-288. Seed weight differed among varieties. IT98K-573-2-1 and IT99K-241-2 had similar seed weight, which was significantly higher than for IT98K-499-35, IT98K205-8 and IT89KD-288. Similarly, IT98K-499-35 and IT98K-205-8 had similar seed weight, which was lower than for IT89KD-288. The differences among varieties were significant for fodder yield. The late maturing varieties produced significantly more fodder yields with IT99K-241-2 being the highest, followed by the medium maturing variety IT98K573-2-1. Early maturing variety IT98K-205-8 produced the lowest fodder yield. Varietal differences also occurred for grain yield. The medium maturing variety IT98K5732-1 had the highest grain yield, followed by the late maturing variety IT99KD-241-2; then medium maturing IT97K-499-35 and early maturing IT98K205-8 which had comparable grain yields, and followed by the late maturing IT89KD-288.

A summary of the interactions among year, sowing date and variety is presented in Table 1 . The interaction between year and sowing date was not significant for number of pods, number of seeds, seed weight, fodder yield and grain yield. Number of pods, number of seeds, fodder yield and grain yield were not influenced by year $x$ variety interaction. Year $x$ variety interaction was however, significant for seed weight and this was mainly due to changes in the magnitude of difference among the varieties between the two years. Sowing date $x$ variety interaction was significant for number of pods, seed weight and fodder yield and not for number of seeds and grain yield. There was no significant year $\times$ sowing date $\times$ variety interaction for any of the studied attributes. The significant sowing date $x$ variety interaction for number of pods showed that IT98K-573-2-1 produced the highest number of pods irrespective of the sowing date; number of pods significantly improved in IT99K-241-2 for 31 July sowing, while IT89KD-288 consistently recorded the lowest number of pods for all the sowing dates (Table 2). The significant sowing date $\mathrm{x}$ variety interaction for seed weight revealed that all the varieties except IT89KD-288 maintained their rankings at all sowing dates (Table 3). Seed weight of IT89KD-288 reduced at 24 and 31 July sowings. Sowing date $x$ variety interaction for fodder yield showed that for the 10-24 July sowings, the late maturing varieties had higher fodder yield than other varieties. However, for the 31 July sowing, there was no significant difference between these varieties and IT98K-573-2-1 in fodder yield. Generally, for the late maturing cowpea varieties, fodder yield decreased with later sowings, whereas there were slight increases for the early and medium maturing varieties.

Table 1. Effects of year, sowing date and variety on the performance of cowpea varieties at Minjibir in Nigerian Sudan savannah

\begin{tabular}{|c|c|c|c|c|c|}
\hline Treatment & $\begin{array}{c}\text { Number of } \\
\text { pods } \\
\left(\text { No. } \mathrm{m}^{-2}\right)\end{array}$ & $\begin{array}{l}\text { Number of } \\
\text { seeds } \\
\left(\text { No. } \mathrm{m}^{-2}\right)\end{array}$ & $\begin{array}{l}100 \text {-seeds } \\
\text { weight }(\mathrm{g})\end{array}$ & $\begin{array}{c}\text { Fodder yield } \\
\left(\mathrm{kg} \mathrm{ha}^{-1}\right)\end{array}$ & $\begin{array}{c}\text { Grain yield (kg } \\
\left.\mathrm{ha}^{-1}\right)\end{array}$ \\
\hline \multicolumn{6}{|l|}{ Year $(\mathrm{Y})$} \\
\hline 2009 & 89.2 & 634.3 & 17.0 & 2993.5 & 954.6 \\
\hline 2010 & 110.6 & 804.7 & 15.2 & 4486.2 & 1133.4 \\
\hline $\operatorname{LSD}_{(\mathrm{P} \leq 0.05)}$ & 11.45 & 94.53 & 0.72 & 384.10 & 118.73 \\
\hline \multicolumn{6}{|l|}{ Sowing Date (D) } \\
\hline 10-July & 76.0 & 513.0 & 16.3 & 3921.6 & 687.0 \\
\hline 17-July & 92.0 & 648.0 & 16.6 & 3784.6 & 862.3 \\
\hline 24-July & 107.0 & 832.0 & 15.8 & 3726.3 & 1213.9 \\
\hline 31-July & 124.0 & 884.0 & 15.8 & 3527.1 & 1413.0 \\
\hline $\operatorname{LSD}_{(P \leq 0.05)}$ & 16.20 & 133.70 & $1.02^{\mathrm{ns} t}$ & $543.26^{\mathrm{ns}}$ & 167.90 \\
\hline \multicolumn{6}{|l|}{ Variety (V) } \\
\hline IT89KD-288 & 46.0 & 294.0 & 15.5 & 5232.2 & 425.5 \\
\hline IT99K-241-2 & 104.0 & 604.0 & 20.8 & 6006.4 & 1155.3 \\
\hline IT97K-499-35 & 99.0 & 728.0 & 13.3 & 2120.7 & 957.2 \\
\hline IT98K-573-2-1 & 158.0 & 1290.0 & 17.2 & 3868.6 & 1876.1 \\
\hline IT98K-205-8 & 93.0 & 682.0 & 13.6 & 1471.7 & 805.9 \\
\hline $\operatorname{LSD}_{(P \leq 0.05)}$ & 12.10 & 103.90 & 0.76 & 431.94 & 157.26 \\
\hline \multicolumn{6}{|l|}{ Interactions } \\
\hline$Y \times D$ & 0.5471 & 0.9509 & 0.4024 & 0.6869 & 0.8786 \\
\hline $\mathrm{Y} \times \mathrm{V}$ & 0.2386 & 0.1274 & 0.0004 & 0.6235 & 0.1096 \\
\hline $\mathrm{D} \times \mathrm{V}$ & 0.0104 & 0.0878 & $<.0001$ & $<.0001$ & 0.0515 \\
\hline $\mathrm{Y} \times \mathrm{D} \times \mathrm{V}$ & 0.5759 & 0.8921 & 0.0681 & 0.4083 & 0.7564 \\
\hline
\end{tabular}

tns, not significant. 
Table 2. Interactive effects of sowing date and variety on number of pods in cowpea varieties at Minjibir in Nigerian Sudan savannah

\begin{tabular}{lllll}
\hline & \multicolumn{3}{c}{ Sowing date (D) } \\
\cline { 2 - 5 } Variety $(\mathrm{V})$ & 10-Jul & 17-Jul & 24-Jul & 31-Jul \\
\cline { 2 - 5 } & 35.0 & 36.0 & 44.0 & 68.0 \\
IT89KD-288 & 67.0 & 80.0 & 118.0 & 150.0 \\
IT97K-241-2 & 79.0 & 99.0 & 106.0 & 110.0 \\
IT97K-499-35 & 147.0 & 154.0 & 161.0 & 170.0 \\
IT98K-573-2-1 & 54.0 & 90.0 & 106.0 & 122.0 \\
IT98K-205-8 $^{-2}$ & 24.12 & & & \\
LSD $_{(P \leq 0.05)}$ D $\times V$ & & & & \\
\hline
\end{tabular}

Table 3. Interactive effects of sowing date and variety on seed weight in cowpea varieties at Minjibir in Nigerian Sudan savannah

\begin{tabular}{|c|c|c|c|c|}
\hline \multirow[b]{2}{*}{ Variety (V) } & \multicolumn{4}{|r|}{ Sowing date (D) } \\
\hline & 10-Jul & 17-Jul & 24-Jul & 31-Jul \\
\hline & \multicolumn{4}{|r|}{ 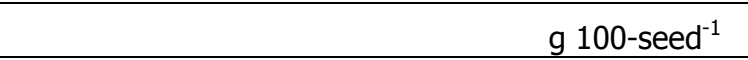 } \\
\hline IT89KD-288 & 18.1 & 17.1 & 13.0 & 14.0 \\
\hline IT97K-241-2 & 20.1 & 20.9 & 21.7 & 20.4 \\
\hline IT97K-499-35 & 12.6 & 12.8 & 13.7 & 14.2 \\
\hline IT98K-573-2-1 & 17.3 & 17.6 & 17.2 & 16.9 \\
\hline IT98K-205-8 & 13.1 & 14.7 & 13.4 & 13.3 \\
\hline $\operatorname{LSD}_{(\mathrm{P} \leq 0.05)} \mathrm{D} \times \mathrm{V}$ & 1.53 & & & \\
\hline
\end{tabular}

Table 4. Interactive effects of sowing date and variety on fodder yield in cowpea varieties at Minjibir in Nigerian Sudan savannah

\begin{tabular}{lllll}
\hline & \multicolumn{3}{c}{ Sowing date (D) } \\
\cline { 2 - 5 } Variety $(\mathrm{V})$ & 10-Jul & 17-Jul & 24-Jul & 31-Jul \\
\hline & & & \multicolumn{1}{c}{$\mathrm{Kg} \mathrm{ha}^{-1}$} \\
IT89KD-288 & 6001.2 & 5786 & 5150.8 & 3990.8 \\
IT97K-241-2 & 7597.4 & 5978 & 5551.7 & 4898.3 \\
IT97K-499-35 & 1671.5 & 2129.7 & 2218.6 & 2462.9 \\
IT98K-573-2-1 & 3633.3 & 3816.2 & 3783.2 & 4241.6 \\
IT98K-205-8 & 704.3 & 1213.2 & 1927.3 & 2041.8 \\
LSD $_{(\mathrm{P} \leq 0.05)} \mathrm{D} \times \mathrm{V}$ & 863.9 & & & \\
\hline
\end{tabular}

\section{DISCUSSION}

Late sowing resulted in higher number of pods, higher number of seeds and higher grain yield. This is because at this time rains have well established for vigorous early vegetative growth. Similar finding has been reported for Samaru in northern Nigeria, where the best yields of cowpea were obtained by sowing at the end of July (Yayock and Asenime, 1977). Sudan savannah is characterised by short growing period or recurrent drought. Rainfall in the zone is unreliable and its distribution is erratic at the beginning and end of the growing season (Eckebeil, 1991). Therefore, sowing cowpea late in the month of July would ensure that the rains are already steady and that the cowpea would have accumulated enough biomass with enough time left for reproductive activities. However,
Kamara et al. (2010a) reported that sowing in early August and mid-August was best for late maturing and early maturing cowpea respectively, in the savannahs of north-eastern Nigeria. Earlier, Asante et al. (2001) reported that for protected and unprotected cowpea evaluated at Minjibir in the Sudan Savannah of Nigeria, cost-benefit analysis indicated that insecticide application was more profitable for cowpea sown in late July and August than was the case when sown in June and early July, suggesting that it will be more profitable for a farmer who could afford to spray to delay planting till late July. They opined that this will ensure clean seeds since the cowpea will mature towards the end of the rainy season or the beginning of dry season. 
The varietal differences in yield and yield components may be due to genetic variation among varieties. Other workers (Ayaz et al., 2004; Kamara et al., 2010b) have reported differences in the performance of cowpea varieties. In the present study, IT98K-5732-1 was found to perform better in grain yield compared to other varieties because it had more pods and seeds with higher seed weight. Variety IT99K241-2 also had an appreciable grain yield because of its large seed size with higher seed weight. On the other hand, IT89KD-288 had poor grain yield because it produced lower number of pods, lower number of seeds and lower seed weights. Grain yield has been found to be significantly and positively associated with number of pods, number of seeds and seed weight in legumes (Kuruvadi and Escober, 1987; Kumar and Hirochika, 2001). Kamara et al. (2010a) reported that medium maturing cowpea variety IT89KD-391 produced significantly higher grain yield than late maturing IT89KD-288 in Sudan savannah of northeastern Nigeria which corroborates the finding in the present study.

The sowing date $x$ variety interaction recorded for number of pods, seed weight and fodder yield suggests that the varieties responded differently to sowing date for these traits. This may be due to the fact that the cowpea varieties evaluated had different growth habits. Variety IT89KD-288 produced lowest number of pods compared with other varieties at all sowing dates. Ranking of the variety, however, changed for seed weight and fodder yield at the different sowing dates. Moreover, there was higher seed weight and fodder yield at earlier sowings than at later sowings. These findings may be due to the fact that IT89KD-288 is a late maturing indeterminate photosensitive variety. Therefore, lower plant populations would be necessary for higher productivity. The ranking of IT99K-241-2 changed for number of pods with different sowing date but was consistent for seed weight and fodder yield at all sowing dates. This may be so because the variety is large-seeded, late, indeterminate and nonphotosensitive. Rankings among the early and

\section{REFERENCES}

Asante, S.K, M. Tamo and L.E.N. Jackai (2001). Integrated Management of Cowpea Insect Pests Using Elite Cultivars, Date of Planting and Minimum Insecticide Application. African Crop Science Journal, 9(4):655-665.

Ayaz, S.B., A. Mckenzie, G.D. Hill and D.L.Mcneil (2004). Variability in Yield of Four Grain Legume Species in a Sub-Humid Temperate Environment, II. Yield Components. Journal of Agricultural Science, 142: 21-28. DOI:10.1017/S0021859604004113.

Eckebil, J.P. (1990). New Frontiers of Food Grain Research for the 90s. In: Menyonga, J.M., Taye-Bezuneh, J.Y. Yayock and I. Soumana, (eds.). Progress in Food Grain Legume and Production in Semi-Arid Africa, pp 3-20. OAU, STRC-SAFGRAD, Burkina Faso. medium maturing varieties were more or less stable at all sowing dates. These varieties may not have attained their full potential at the sowing dates. Increase in plant populations of these early and medium maturing varieties may contribute towards higher yields at the given sowing dates. Generally, all the varieties had yield increment with later sowing. This may mean that optimum yield may be realized beyond late July sowing.

\section{CONCLUSION}

Sowing date and cowpea variety significantly influenced yield and yield components. Highest grain yield was achieved for 31 July sowing. IT98K-573-2-1 out-yielded the other varieties, although grain yields greater than $0.8 \mathrm{t} / \mathrm{ha}$ was recorded for IT97K-499-35, IT98K-205-8 and IT99K-241-2. The indeterminate late maturing varieties produced the highest fodder yields. Decreasing the plant population of the late maturing indeterminate photosensitive variety IT89KD-288 is suggested to achieve lower fodder yield but higher grain yield, whereas, the plant population of the early and medium maturing varieties be increased to raise their grain yield. The yield of all the varieties may be further improved by sowing beyond late July.

\section{Contribution of Authors}

Tofa, A.I. conducted the 2009 field trial and prepared the draft manuscript for the combined analysis. Ewansiha S.U. conducted the 2010 field trial, carried out the data analysis, constructed the tables and prepared the final draft of the manuscript.

\section{Conflict of Interest}

There are no conflicts of interest between the authors, between the authors and any other person/institution where the study was carried out.

\section{Acknowledgements}

The authors would like to thank Dr. A.Y. Kamara for providing research support and the International Institute of Tropical Agriculture (IITA), Nigeria, for providing research field and institutional support.

Ehlers, J.D. and A.E. Hall (1996). Genotypic Classification of Cowpea Based on Response to Heat and Photoperiod. Crop Science, 36:673-679.

Ewansiha, S.U, A.Y. Kamara, U.F. Chiezey and J.E. Onyibe (2015). Response of Cowpea to Sowing Date and Maize Plant Population in a Sudan Savannah environment. Tropical Agriculture (Trinidad), 92(1): 80-91.

Gallagher, J.N. and P.V. Biscoe (1978). A Physiological Analysis of Cereal Yield. II. Partitioning of Dry Matter. Agricultural Progress 53:51-70.

Hall, A.E. (2012). Phenotyping Cowpea for Adaptation to Drought. Frontiers in Physiology, 3 (155):1-8. Doi:10.3389/fphys.2012.00155.

IITA (2009). Crops. [Online] Available: http://www.iita.org [Accessed 2014 May 01]. 
Kamara, A.Y., F. Ekeleme, L.O. Omoigui, T, Abdoulaye, P. Amaza, D. Chikoye and I.Y. Dugje (2010a). Integrating Planting Date with Insecticide Spraying Regimes to Manage Insect Pests of Cowpea in North-eastern Nigeria. International Journal of Pest Management, 56:243-253.

Kamara, A.Y., J. Ellis-Jones, F. Ekeleme, L.O. Omoigui, P. Amaza, D. Chikoye and I.Y. Dugje (2010b). A Participatory Evaluation of Improved Cowpea Cultivars in the Guinea and Sudan Savanna Zones of Northeast Nigeria. Archive of Agronomy and Soil Science, 56 (3):355-358.

Kumar, A. and H. Hirochika (2001). Applications of Retrotransposons as Genetic Tools in Plant Biology. Trends in Plant Science, 6: 127-134.

Kuruvadi, S. and C.M.H. Escober (1987). Genotypic and Phenotypic Correlations in Soybeans and their Implications in Selection. Agronomy Journal, 43: 107-153.
Muleba, N. and H.C. Ezumah (1985). Optimizing Cultural Practices for Cowpea in Africa. In: Singh, S.R. and K.O. Rachie (eds.). Cowpea Research, Production and Utilization, pp 290-295. John Wiley and Sons Ltd, Chichester, UK.

Patel, P.N. and A.E. Hall (1996). Registration of Snap Cowpea Germplasm. Crop Science, 26: 207208.

SAS Institute Inc. (2011) The SAS system for Windows.SAS Institute Inc., Cary, NC, USA.

Weber, G., K. Elemo, S.T.O. Lagoke and S. Oiken (1995). Population Dynamics and Determinants of Striga Hermonthica on Maize and Sorghum in Savanna Farming Systems. Crop protection, 14:283-290.

Yayock J.Y. and E. Asenime 1977. Effects of Fertilizer, Plant Density and Sowing Date on Yield and Other Characters of Cowpea (Vigna unguiculata) in Northern Nigeria, Samaru. Miscellaneous Paper, 69. p. 17 